DOI: https://doi.org/10.24127/ajpm.v10i4.4143

\title{
PENGARUH MODEL CREATIVE PROBLEM SOLVING TERHADAP KEMAMPUAN PEMECAHAN MASALAH MATEMATIS DITINJAU DARI MOTIVASI BELAJAR SISWA
}

\author{
Neni $^{1}$, Syaiful ${ }^{2}$, Maison $^{3}$ \\ ${ }^{1,2}$ Pendidikan Matematika, Universitas Jambi , Jambi, Indonesia \\ ${ }^{3}$ Pendidikan Fisika, Universitas Jambi, Jambi, Indonesia \\ *Jambi, 36361, Jambi, Indonesia. \\ E-mail: $\quad$ nenibae9916@gmail.com ${ }^{\left.{ }^{*}\right)}$ \\ pak_bakri@unja.ac.id ${ }^{2)}$ \\ maison@unja.ac.id ${ }^{3)}$
}

Received 23 August 2021; Received in revised form 17 November 2021; Accepted 27 December 2021

\begin{abstract}
Abstrak
Penelitian ini bertujuan untuk mengetahui pengaruh model pembelajaran Creative Problem Solving (CPS) terhadap kemampuan pemecahan masalah matematis siswa, dan pengaruh motivasi belajar terhadap kemampuan pemecahan masalah matematis siswa, serta interaksi antara model pembelajaran CPS dan motivasi belajar siswa terhadap kemampuan pemecahan masalah matematis siswa. Penelitian ini merupakan penelitian eksperimen yang menggunakan posttest only control design. Populasi penelitian ini adalah seluruh siswa kelas VII SMP Negeri 5 Kota Jambi tahun ajaran 2021/2022 sebanyak 325 siswa dan terbagi menjadi 11 kelas. Dalam penelitian ini, sampel yang digunakan adalah sebanyak 66 siswa yang terbagi menjadi dua kelas (kelas eksperimen I dan kelas kontrol). Sampel di tentukan dengan teknik Random Sampling. Teknik pengambilan data yang digunakan dalam penelitian ini merupakan angket motivasi belajar dan tes pemecahan masalah matematis. Data yang diperoleh dianalisis menggunakan uji ANOVA dua jalur. Hasil penelitian ini yaitu Model pembelajaran CPS lebih efektif mempengaruhi kemampuan pemecahan masalah dibandingkan model pembelajaran konvensional, dan Motivasi belajar tinggi dan sedang lebih efektif mempengaruhi kemampuan pemecahan masalah dibandingkan motivasi rendah serta tidak terdapat interaksi antara model pembelajaran CPS dengan motivasi belajar terhadap kemampuan pemecahan masalah matematis siswa.
\end{abstract}

Kata kunci: Model pembelajaran CPS, Motivasi belajar, Pemecahan masalah matematis

\begin{abstract}
This study aims to determine the effect of the Creative Problem Solving (CPS) learning model on students' mathematical problem solving abilities, and the effect of learning motivation on students' mathematical problem solving abilities, as well as the interaction between the CPS learning model and students' learning motivation on students' mathematical problem solving abilities. This research is an experimental study using a posttest only control design. The population of this research is all 7 th grade students of SMP Negeri 5 Jambi City in the 2021/2022 academic year as many as 325 students and divided into 11 classes. In this study, the sample used was 66 students who were divided into two classes (experimental class I and control class). The sample is determined by the Random Sampling technique. The instrument used in this research is a learning motivation questionnaire and a mathematical problem solving test. The data obtained were analyzed using a two-way ANOVA test. The results of this study are that the CPS learning model is more effective in influencing problem solving abilities than conventional learning models, and high and moderate learning motivations are more effective in influencing problem solving abilities than low motivation and there is no interaction between the CPS learning model and learning motivation on students' mathematical problem solving abilities.
\end{abstract}

Keywords: CPS learning model, Learning motivation, Mathematical problem solving,

This is an open access article under the Creative Commons Attribution 4.0 International License 
DOI: https://doi.org/10.24127/ajpm.v10i4.4143

\section{PENDAHULUAN}

Menurut Amrina (2020), matematika adalah mata pelajaran yang memiliki tujuan yang membutuhkan suatu keterampilan dan jalan untuk memecahkan suatu masalah dalam hitung menghitung. Sedangkan menurut Semiz (2020) tujuan dari pembelajaran matematika adalah untuk membuat siswa mengerti tentang apa yang dipelajarinya dalam memecahkan masalah.

Pemecahan masalah itu sendiri merupakan suatu proses penerapan pengetahuan yang telah dimiliki sebelumnya kedalam kondisi dan situasi baru. Poin dan hasil dari ukuran pemecahan masalah merupakan letak pentingnya dalam menyelesaikan masalah matematika (Dahn, 2020)

Namun menurut Uszyńska \& Jarmoc (2020) sejumlah besar peserta didik belum memperoleh keterampilan dasar yang mereka butuhkan dalam matematika. Akibatnya, banyak peserta didik dilaporkan menghadapi kesulitan dalam matematika, khususnya dalam pemecahan masalah matematis.

Salah satu alternatif dan stategi model pembelajaran yang baik digunakan adalah Creative Problem Solving (CPS), model ini bisa membimbing peserta didik untuk mengetahui ide, mendapatkan ide, serta memberikan solusi dalam suatu pemecahan masalah terutama matematika. Dalam hal ini guru memberikan masalah yang akan dikerjakan peserta didik yang dicocokan dengan masalah dikehisupan seharihari, memberikan rasa keingintahuan peserta didik, serta menyusun strategi pemecahan masalah, sehingga peserta didik memperoleh solusi dengan menggunakan strategi terbaik. Hal ini sejalan dengan penelitian yang dilakukan oleh Muhammad (2015) yang menunjukan adanya pengaruh penerapan model pembelajaran CPS terhadap kemampuan pemecahan masalah matematis siswa. Demikian pula penelitian yang dilakukan oleh peneliti (Nopitasari, 2016) menunjukan bahwa pemecahan masalah matematis siswa yang diikuti oleh model creative problem solving lebih meningkat dibandingkan dengan model pembelajaran konvensional, hal ini karena model CPS dapat mengembangkan ide dan pemikiran.

Selain itu cara untuk mengerjakan matematika dijaman sekarang harus ada suatu motivasi baik dalam diri maupun dari luar. Terlebih di masa pandemik dengan model pembelajaran jarak jauh atau daring. Peran penting motivasi dalam pembelajaran jarak jauh diakui dalam penelitian yang diterbitkan dalam edisi awal Pendidikan Jarak Jauh. Motivasi itu sendiri merupakan dorongan dari dalam diri untuk melakukan sesuatu agar hal yang dikerjakan sesuai dengan tujuan yang diinginkan. Bahkan menurut Sugiaryo \& Sutoyo (2019) motivasi itu merupakan suatu situasi psikologis seseorang untuk melakukan sesuatu, bahkan motivasi itu sendiri merupakan hal yang paling penting dalam proses belajar mengajar. Penelitian ini memiliki tujuan untuk mengetahui serta mengkaji kembali bagaimana pengaruh model pembelajaran creative problem solving (CPS) terhadap pemecahan masalah matematis siswa, dan ingin mengetahui seberapa pengaruhnya motivasi belajar terhadap kemampuan pemecahan masalah matematis siswa, serta untuk mengetahui Apakah ada interkasi antara model pembelajaran dan motivasi belajar terhadap kemampuan pemecahan masalah matematis siswa. 
DOI: https://doi.org/10.24127/ajpm.v10i4.4143

\section{METODE PENELITIAN}

Penelitian pada saat ini merupakan penelitian eksperimen. Populasi pada penelitian ini adalah semua kelas VII SMP Negeri 5 Kota jambi yang berjumlah 325 siswa yang terbagi menjadi 11 kelas. Penelitian ini dilakukan dengan teknik random sampling. Sampel terdiri dari 66 siswa dimana terdapat 2 kelas yaitu kelas eksperimen (menggunakan model pembelajaran CPS) dan kelas kontrol (menggunakan model pembelajran konvensional). Kelas VII-A merupakan kelas eksperimen yang terdiri dari 34 siswa dan kelas VII-H sebagai kelas kontrol yang terdiri dari 32 siswa.

Dalam penelitian ini terdiri dari tiga variabel yaitu variabel bebas, variabel terikat dan variabel moderator. Variabel bebas terdiri dari model pembelajaran, variabel terikat terdiri dari pemecahan masalah matematis dan variabel moderator adalah motivasi belajar. Penelitian ini menggunakan posttest only control design. Selanjutnya rancangan penelitian dapat dilihat pada table 1 .

Tabel 1. Rancangan Penelitian

\begin{tabular}{lcc}
\hline \multicolumn{1}{c}{ Kelas } & Perlakuan & $\begin{array}{c}\text { Post- } \\
\text { test }\end{array}$ \\
\hline $\begin{array}{l}\text { Eksperimen } \\
(C P S)\end{array}$ & $X_{1}$ & $O_{2}$ \\
$\begin{array}{l}\text { Kontrol } \\
\text { (konvensional) }\end{array}$ & $X_{2}$ & $O_{2}$ \\
\hline
\end{tabular}

Keterngan :

$X_{1}$ : Perlakuan dengan model CPS

$X_{2}$ : Perlakuan dengan model konvensional

Dalam penelitian ini, langkahlangkah eksplorasi yang diselesaikan adalah sebagai berikut:

1. Studi pendahuluan yaitu melakukan studi literatur terhadap teori yang relevan mengenai pembelajaran yang akan digunakan serta menganalisis kurikulum matematika SMP Negeri 5 Kota Jambi.

2. Menetapkan jadwal penelitian yaitu jadwal penelitian disesuaikan dengan jadwal yang telah ditentukan oleh guru mata pelajaran Matematika kelas VII di SMP Negeri 5 Kota Jambi.

3. Menentukan kelas sampel penelitian yaitu kelas sampel penelitian terdiri dari dua kelas eksperimen dan satu kelas kontrol.

4. Mempersiapkan (RPP), RPP dibuat dengan berpatokan pada silabus dan dibuat sesuai dengan kebutuhan penelitian dengan model pembelajaran.

5. Mempersiapkan Lembar Kerja Peserta Didik (LKPD), LKPD yang dibuat akan diberikan kepada peserta didik kelas eksperimen.

6. Siapkan instrumen penelitian, yaitu instrumen ujian khusus yang digunakan melalui survei motivasi belajar, tes kemampuan pemecahan masalah matematis.

7. Memvalidasi RPP, LKPD dan instrumen penelitian dengan menggunakan lembar validasi.

8. Melakukan pengajaran atau penerapan model dan melakukan post-test

9. Memberikan angket

10. Data diolah untuk menjawab semua hipotesis.

11. Menyusun laporan penelitian

Angket dan tes merupakan instrument yang dipakai dalam penelitian ini. Angket yang digunakan terdiri dari 27 pertanyaan, angket ini menggunakan skala likert. Sedangkan instrument berupa tes yaitu tes kemampuan pemecahan masalah matematis siswa yang terdiri dari 3 soal. Materi yang diberikan yaitu materi 
bilangan dengan indikator yang telah ditentukan.

Uji yang dilakukan dalam teknik analisis dalam penelitian ini terdiri dari :

1. Uji Validitas Isi angket

Uji validitas isi angket ini diuji oleh ahli yaitu dosen pasca sarjana UNJA

2. Uji Validitas Konstruk

Untuk perhitungan validitas butir soal menggunakan rumus product moment. Hasilnya dari 3 butir soal tes kemampuan pemecahan masalah matematis siswa yang telah diuji cobakan semua soal valid. Sedangkan 27 butir pertanyaan angket motivasi belajar siswa yang telah diuji cobakan 26 valid dan 1 tidak valid yaitu no. 19

3. Uji Reliabilitas

Pada uji reliabilitas ini menggunakan rumus alpha. Hasilnya yaitu tes kemampuan pemecahan masalah matematis siswa sebesar 0,68 dengan keterangan reliabilitas tinggi. Sedangkan untuk uji reabilitas angket sebesar 0,87 dengan keterangan reliabilitas tinggi.

4. Uji Daya Beda dan Tingkat Kesukaran Tes

Hasilnya yaitu untuk soal no 1 memiliki daya beda Cukup dan tingkat kesukarannya dalam kategori sukar, soal no 2 daya bedanya baik dan tingkat kesukarannya sedang, sedangkan no 3 baik daya beda cukup dan tingkat kesukaran sedang.

Setelah uji analisis dilakukan maka selanjutnya dilakukan uji prasyarat hipotesis, diantaranya uji normalitas, homogenitas dan terakhir uji hipotesis menggunakan Anova Dua arah.

\section{HASIL DAN PEMBAHASAN}

Data yang terkumpul dalam penelitian ini terdiri atas data motivasi belajar dan data kemampuan pemecahan masalah matematis siswa pada materi bilangan. Data diperoleh dari kelas eksperimen I dengan menggunakan model CPS, kelas kontrol dengan menggunakan model konvensional. Data motivasi ini diperoleh melalui angket tentang motivasi belajar, adapun hasil motivasi belajar siswa dapat disajikan pada gambar 1 .

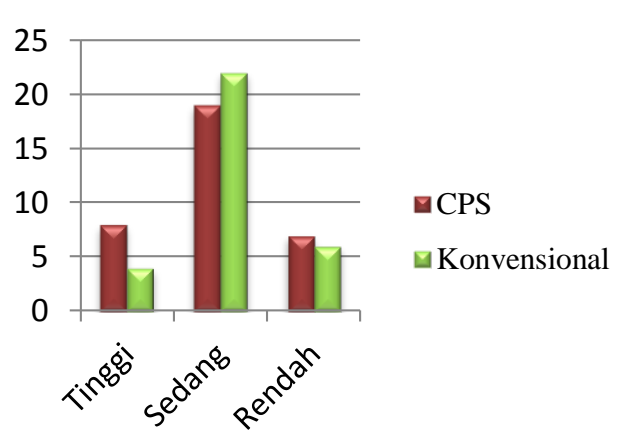

Gambar 1. Grafik Distribusi Frekuensi Motivasi Belajar

Dari gambar.1 terlihat bahwasannya motivasi belajar siswa yang lebih banyak yaitu dalam katagori sedang baik alam pembelajaran yang memakai model CPS maupun Konvensional

Dan untuk data Kemampuan pemecahan masalah matematis ini diperoleh melalui tes, tes ini dilakukan untuk mengukur pemecahan masalah matematis siswa. Adapun hasilnya dapat disajikan dalam tabel 2 .

Tabel 2. Data kemampuan pemecahan masalah matematis

\begin{tabular}{lccccc}
\hline \multicolumn{1}{c}{ Model } & Data & Mean & SD & Min & Mak \\
\hline Eksperimen & 34 & 20,2 & 6,6 & 0 & 30 \\
Kontrol & 32 & 18,2 & 4,5 & 5 & 27 \\
\hline
\end{tabular}

Selanjutnya untuk melihat distribusi frekuensi pemecahan masalah terhadap model pembelajaran bisa dilihat pada Gambar 2 dan Gambar 3. 


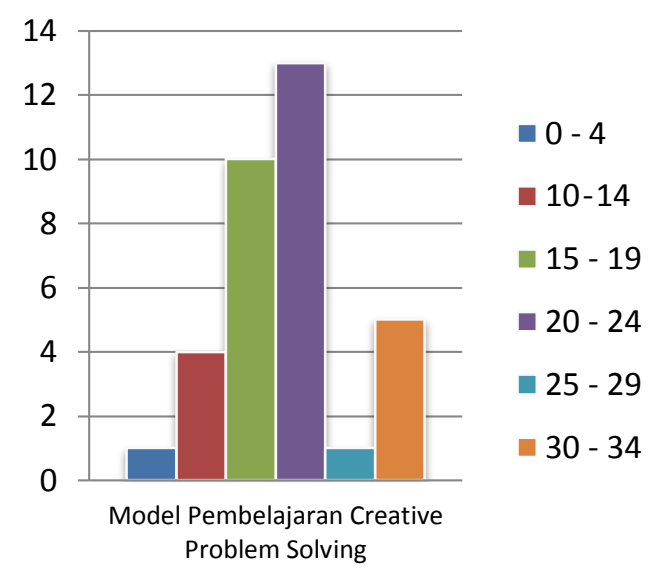

Gambar 2. Distribusi Frekuensi Pemecahan Masalah Matematis Pada Model CPS

Gambar 2 menyatakan bahwasannya dari pembelajaran yang memakai model CPS interval yang paling tinggi yaitu interval dari 20-24 sebanyak 13, dan interval yang paling rendah yaitu 0-4 sebanyak 1

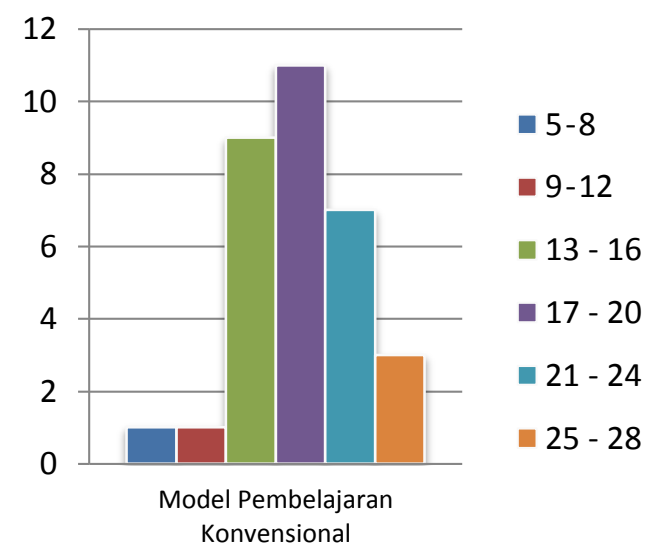

Gambar 3. Distribusi Frekuensi

Pemecahan Masalah Matematis Pada Model Konvensional

Gambar 3 menyatakan bahwasannya dari pembelajaran yang memakai model Discovery Learning interval yang paling tinggi yaitu interval dari 17-20 sebanyak 13, dan interval yang paling rendah yaitu 5-8 dan 9-12 masing-masing sebanyak 1
Kemudian dilakukan uji normalitas kemampuan pemecahan masalah matematis siswa berdasarkan model pembelajaran yang disajikan pada Tabel 3.

Tabel 3. Uji Normalitas Kemampuan Pemecahan Masalah Matematis Siswa Berdasarkan Model Pembelajaran

\begin{tabular}{|c|c|c|c|c|}
\hline $\begin{array}{c}\text { Model } \\
\text { Pembelajara } \\
\mathbf{n}\end{array}$ & $\begin{array}{c}\text { Statisti } \\
\mathbf{k} \\
\text { Hitung }\end{array}$ & df & $\begin{array}{c}p- \\
\text { valu } \\
e\end{array}$ & $\begin{array}{r}\text { Keputasa } \\
\text { n }\end{array}$ \\
\hline CPS & 0,131 & $\begin{array}{l}3 \\
4\end{array}$ & $\begin{array}{c}0,15 \\
1\end{array}$ & Normal \\
\hline Konvensional & 0.109 & $\begin{array}{l}3 \\
2\end{array}$ & $\begin{array}{c}0,20 \\
0\end{array}$ & Normal \\
\hline
\end{tabular}

Dari Tabel 3 dapat dikatakan bahwa pemecahan masalah matematis berdasarkan model pembelajaran berasal dari populasi yang berdistribusi "Normal". Karena berdistribusi normal maka data tersebut bisa digunakan untuk uji lanjut.

Uji Normalitas kemampuan pemecahan masalah matematis siswa berdasarkan motivasi belajar siswa yang disajikan pada Tabel 4.

Tabel 4. Uji Normalitaskemampuan Pemecahan Masalah Matematis Siswa Berdasarkan Motivasi Belajar

\begin{tabular}{ccccc}
\hline $\begin{array}{c}\text { Motivas } \\
\mathbf{i} \\
\text { Belajar }\end{array}$ & $\begin{array}{c}\text { Statisti } \\
\mathbf{k} \\
\text { Hitung }\end{array}$ & $\begin{array}{c}\text { df } \\
\text { palu } \\
\text { valu }\end{array}$ & $\begin{array}{c}\text { Keputasa } \\
\mathbf{n}\end{array}$ \\
\hline Tinggi & 0,147 & 1 & 0,20 & Normal \\
& & 6 & 0 & \\
Sedang & 0,111 & 3 & 0,05 & Normal \\
& & 1 & 6 & \\
Rendah & 0,134 & 1 & 0,20 & Normal \\
& & 9 & 0 & \\
\hline
\end{tabular}

Dari Tabel 4 dapat dikatakan bahwa pemecahan masalah matematis berdasarkan motivasi belajar berasal dari populasi yang berdistribusi "Normal". Karena berdistribusi normal maka data tersebut bisa digunakan untuk uji anava dua arah. 
DOI: https://doi.org/10.24127/ajpm.v10i4.4143

Uji Normalitas kemampuan pemecahan masalah matematis siswa berdasarkan interaksi yang disajikan pada Tabel 5.

Tabel 5. Uji Normalitas Kemampuan Pemecahan Masalah Matematis Siswa Berdasarkan Model Pembelajaran

\begin{tabular}{|c|c|c|c|c|}
\hline Interaksi & $\begin{array}{c}\text { Statisti } \\
\mathbf{k} \\
\text { Hitung }\end{array}$ & df & p-value & $\begin{array}{c}\text { Keputa } \\
\text { san }\end{array}$ \\
\hline $\mathrm{A}_{1} \mathrm{~B}_{1}$ & 0,199 & 8 & 0,291 & Normal \\
\hline $\mathrm{A}_{1} \mathrm{~B}_{2}$ & 0,155 & 19 & 0,061 & Normal \\
\hline $\mathrm{A}_{1} \mathrm{~B}_{3}$ & 0,209 & 7 & 0,725 & Normal \\
\hline $\mathrm{A}_{2} \mathrm{~B}_{1}$ & 0,155 & 4 & 0,995 & Normal \\
\hline $\mathrm{A}_{2} \mathrm{~B}_{2}$ & 0,149 & 21 & 0,233 & Normal \\
\hline $\mathrm{A}_{2} \mathrm{~B}_{3}$ & 0,129 & 7 & 0.991 & Normal \\
\hline
\end{tabular}

bahwa pemecahan masalah matematis berdasarkan interasksi berasal dari populasi yang berdistribusi "Normal". Karena berdistribusi normal maka data tersebut bisa digunakan untuk uji anava dua arah.

Kemudian dilakukan uji Homogenitas kemampuan pemecahan masalah matematis siswa berdasarkan model pembelajaran yang disajikan pada Tabel 6.

Tabel 6. Uji Homogenitas kemampuan Pemecahan Masalah Matematis Siswa Berdasarkan Motivasi Belajar

\begin{tabular}{ccccc}
\hline $\begin{array}{c}\text { F- } \\
\text { hitung }\end{array}$ & $\begin{array}{c}\text { db- } \\
\mathbf{1}\end{array}$ & $\begin{array}{c}\text { db- } \\
\mathbf{2}\end{array}$ & $\begin{array}{c}\mathbf{p}- \\
\text { value }\end{array}$ & Keputusan \\
\hline 4,203 & 2 & 64 & 0,085 & Homogen \\
\hline
\end{tabular}

Maka dapat disimpulkan bahwa sampel dalam penelitian berdasarkan model pembelajaran mempunyai varians yang sama. Artinya bahwa data tersebut bisa digunakan untuk uji lanjut.

Kemudian dilakukan uji homogenitas kemampuan pemecahan masalah matematis siswa berdasarkan motivasi belajar yang disajikan pada Tabel 7
Tabel 7. Uji Homogenitas kemampuan Pemecahan Masalah Matematis Siswa Berdasarkan Motivasi Belajar

\begin{tabular}{ccccc}
\hline $\begin{array}{c}\text { F- } \\
\text { hitung }\end{array}$ & db-1 & db-2 & $\begin{array}{c}\text { p- } \\
\text { value }\end{array}$ & Keputusan \\
\hline 2,354 & 2 & 64 & 0,95 & Homogen \\
\hline
\end{tabular}

Maka dapat disimpulkan bahwa sampel dalam penelitian berdasarkan motivasi belajar mempunyai varians yang sama. Artinya bahwa data tersebut bisa digunakan untuk uji lanjut

Uji Homogenitas kemampuan pemecahan masalah matematis siswa berdasarkan interaksi yang disajikan pada Tabel 8.

Tabel 8. Uji Homogenitas kemampuan Pemecahan Masalah Matematis Siswa Berdasarkan Interaksi.

\begin{tabular}{ccccc}
\hline $\begin{array}{c}\text { F- } \\
\text { hitung }\end{array}$ & db-1 & db-2 & $\begin{array}{c}\text { p- } \\
\text { value }\end{array}$ & Keputusan \\
\hline 2,042 & 2 & 64 & 0,130 & Homogen \\
\hline
\end{tabular}

Maka dapat disimpulkan bahwa sampel dalam penelitian berdasarkan interaksi mempunyai varians yang sama. Artinya bahwa data tersebut bisa digunakan untuk uji lanjut

Karena telah memenuhi prayarat maka sudah dapat dilakukan uji Anava dua arah. Hasil disajikan pada Tabel 9.

Tabel 9. Uji Varians Dua Jalur

\begin{tabular}{|c|c|c|c|c|}
\hline \multicolumn{5}{|c|}{ Tests of Between-Subjects Effects } \\
\hline \multicolumn{5}{|c|}{ Dependent Variable: PemecahanMasalahMatematis } \\
\hline Source & $\begin{array}{l}\text { Type III Sum of } \\
\text { Squares }\end{array}$ & df & $\mathrm{F}$ & Sig. \\
\hline Corrected Model & $246.330^{\mathrm{a}}$ & 8 & 1.090 & .378 \\
\hline Intercept & 22246.282 & 1 & 787.303 & .000 \\
\hline MetodePembelajaran & 42.069 & 2 & .053 & .048 \\
\hline MotivasiBelajar & 3.519 & 2 & .002 & .040 \\
\hline $\begin{array}{l}\text { MetodePembelajaran * } \\
\text { MotivasiBelajar }\end{array}$ & 111.109 & 4 & .983 & .421 \\
\hline Error & 2486.557 & 53 & & \\
\hline Total & 36358.000 & 67 & & \\
\hline Corrected Total & 2732.887 & 66 & & \\
\hline \multicolumn{5}{|c|}{ a. R Squared $=.090($ Adjusted R Squared $=.007)$} \\
\hline
\end{tabular}

Hasil uji anava dua arah pada hipotesis pertama menunjukan bahwa nilai signifikansi sebesar $0,048<0,05$ dengan demikian dapat disimpulkan bahwa Terdapat pengaruh model pembelajaran creative problem solving 
DOI: https://doi.org/10.24127/ajpm.v10i4.4143

(CPS), model pembelajaran konvensional terhadap kemampuan pemecahan masalah matematis siswa. Model pembelajaran Creative Problem Solving (CPS) memperoleh nilai mean sebesar 19,5 lebih tinggi dari model Konvensional yaitu sebesar 17,9. Sehingga dapat disimpulkan bahwa model pembelajaran Creative Problem Solving lebih efektif dibanding model pembelajaran konvensional dalam mempengaruhi kemampuan pemecahan masalah matematis siswa.

Creative problem solving yang diterapkan dalam penelitian ini dapat meningkatkan kemampuan peserta didik dalam memecahan masalah matematis seperti yang dikemukakan oleh (Tan, 2020) Creative problem soving (CPS) adalah pendekatan yang berpusat kepada siswa serta dapat meningkatkan kemampuan keterampilan pemecahan masalah. Hal ini juga sejalan dengan penelitian yang dilakukan oleh Puccio et al (2020) bahwa creative problem solving lebih efektif dalam menemukan ide dan melaksanakan ide nya secara kelompok.

Kemudian Süße (2020) juga menyatakan bahwa tujuan akhir yang lebih penting dalam penerapan model CPS adalah memungkinkan siswa meningkatkan kemampuan mereka dalam menghadapi masalah dan tantangan yang nyata dengan sukses dan kreatif hal ini karena dalam penerapan CPS, peserta didik dilibatkan dalam menghadapi peluang dan tantangan.

Hal ini sejalan dengan pendapat yang dikemukan oleh Wahyuningsih (2020) yang menyatakan bahwa saat menggunakan model pembelajaran creative problem solving, siswa dilatih bekerja dalam kelompok untuk melatih kreativitas siswa dalam meneliti dan menemukan konsep penyelesaian matematika.
Hasil uji anava dua arah pada hipotesis kedua menunjukan bahwa nilai signifikansi sebesar $0,040<0,05$ maka dapat disimpulkan bahwa terdapat pengaruh motivasi belajar tinggi, motivasi belajar sedang, dan motivasi belajar rendah terhadap kemampuan pemecahan masalah matematis siswa. Karena $H_{02}$ ditolak maka dilanjutkan dengan uji lanjut dengan menggunakan uji scheffe yang disajikan pada table 10 .

Tabel 10. Uji Scheffe

\begin{tabular}{llc}
\hline $\begin{array}{c}\text { Motivasi } \\
\text { belajar }\end{array}$ & N & $\begin{array}{c}\text { Subset } \\
\mathbf{1}\end{array}$ \\
\hline Rendah & 19 & 18.58 \\
Tinggi & 16 & 18.63 \\
Sedang & 31 & 18.63 \\
Sig & & 1.000 \\
\hline
\end{tabular}

Dari Tabel 10 dapat disimpulkan bahwa motivasi belajar tinggi dan sedang lebih efektif dibandingkan motivasi belajar yang rendah.

Berdasarkan hasil penelitian ini diperoleh bahwa kemampuan peserta didik dalam memecahan masalah matematis yang memiliki motivasi belajar tinggi dan sedang lebih baik dibandingkan peserta didik yang memiliki motivasi belajar rendah. Hal ini dikarenakan motivasi belajar sangat berpengaruh terhadap kemampuan pemecahan masalah matematika siswa. Motivasi sebagai faktor utama dalam belajar yakni berfungsi menimbulkan, mendasari dan menggerakkan perbuatan belajar. Dengan motivasi siswa juga tekun dalam belajar, dengan motivasi juga siswa menjadi berminat dalam belajar matematika. Jika siswa sudah termotivasi untuk belajar matematika maka dengan itu bisa meningkatkan kemampuan pemecahan masalah matematika siswa menjadi lebih baik.

Hal ini sejalan dengan yang dikemukakan oleh (Abel, 2020) bahwa 
DOI: https://doi.org/10.24127/ajpm.v10i4.4143

Motivasi adalah kekuatan batin yang mengaktifkan dan memberikan arahan pada pikiran, perasaan, dan perasaan kita untuk melakukan tindakan. Dua karakteristik utama motivasi adalah perilaku yang diarahkan pada tujuan dan ketekunan. Dengan adanya suatu motivasi dalam diri seseorang maka akan tergerak dalam melakukan suatu pekerjaan yang melibatkan tindakan untuk tujuan yang diinginkan oleh dirinya (Canals, 2020)

Lebih lanjut menurut (Symonenko, 2020) Peserta didik yang memiliki prestasi belajar yang baik jika memiliki motivasi belajar yang baik. Serta pendapat dari Lozano (2020) Motivasi belajar termasuk faktor yang mempengaruhi dan mendukung prestasi belajar.

Hal ini sejalan dengan penelitian sebelumnya yang dilakukan oleh (Zhang, 2020) menunjukkan dampak besar antara motivasi belajar dan kapasitas pemecahan masalah matematis sisw. Juga sejalan dengan penelitian yang dilakukan oleh Farida (2015) bahwa motivasi belajar sangat berpengaruh terhadap prestasi belajar baik itu motivasi dari dalam dirinya sendiri maupun dari luar.

Hasil uji anava dua arah pada hipotesis ketiga menunjukan bahwa nilai signifikansi sebesar $0,421>0,05$ maka dapat disimpulkan tidak ada interaksi secara bersamaan antara model belajar dan motivasi belajar terhadap kemampuan pemecahan masalah matematis siswa.

Hal ini tidak sejalan dengan penelitian yang dilakukan oleh Samara (2016) bahwa ada interaksi atau pengaruh antara model pembelajaran dan motivasi belajar terhadap hasil belajar, serta penelitian yang dilakukan oleh Erita (2017) bahwa terdapat interaksi yang baik antara faktor keberhasilan belajar dan model pembelajaran serta motivasi belajar dari siswa itu sendiri.

\section{KESIMPULAN DAN SARAN}

Berdasarkan hasil penelitian dan pembahasan dapat disimpulkan bahwa terdapat pengaruh model pembelajaran creative problem solving (CPS) terhadap kemampuan pemecahan masalah matematis siswa, dan ada pengaruh motivasi belajar terhadap pemecahan masalah matematis siswa, dan tidak ada interaksi antara model pembelajaran dan motivasi belajar terhadap kemampuan pemecahan masalah matematis siswa.

Berdasarkan penelitian diatas diharapkan peneliti lain bila menggunakan model pembelajaran Creative Problem Solving (CPS) hendaknya jangan sampai menimbulkan salah konsep (misconception). Serta ntuk memperhati-kan motivasi belajar hendaknya melakukan tes tingkat motivasi belajar dan usaha-usaha untuk meningkatkan motivasi belajar siswa.

\section{DAFTAR PUSTAKA}

Abel, M. (2020). Would you like to learn more? Retrieval practice plus feedback can increase motivation to keep on studying. Cognition, 201. https://doi.org/10.1016/j.cognition. 2020.104316

Amrina, Z. (2020). Development of Problem-Based Mathematic Learning Model to Improve Creative Thinking Ability of Elementary Teacher Education Students, Bung Hatta University. Journal of Physics: Conference Series, Vol. 1554. https://doi.org/10.1088/17426596/1554/1/012068 
Canals, L. (2020). The effects of virtual exchanges on oral skills and motivation. Language Learning and Technology, 24(3), 103-119. Retrieved from https://api.elsevier.com/content/abs tract/scopus_id/85107438681

Dahn, M. (2020). Dynamics of emotion, problem solving, and identity: Portraits of three girl coders. Computer Science Education, 30(3), 362-389. https://doi.org/10.1080/08993408.2 020.1805286

Erita, E. (2017). Pengaruh Model Pembelajaran interaktif Terhadap Motivasi Belajar Siswa. Economica, 6(1), 72-86. https://doi.org/10.22202/economic a.2017.v6.i1.1941

Farida, N. (2015). Pengaruh Motivasi Terhadap Prestasi (Studi Kasus Pada Siswa SMK PGRI Sutojayan Blitar). Cendekia, 9(2), 135-148.

Lozano. (2020). A blended learning system to improve motivation, mood state, and satisfaction in undergraduate students: Randomized controlled trial. Journal of Medical Internet Research, Vol. 22. https://doi.org/10.2196/17101

Muhammad, S. (2015). Pengaruh model pembelajaran creative problem solving berbantuan maple II terhadap kemampuan pemecahan masalah matematis Muhamad. Journal of Chemical Information and Modeling, 6(1), 91-98.

Nopitasari, D. (2016). Pengaruh Model Pembelajaran Creative Problem Solving (CPS) terhadap kemampuan penalaran adaptif matematis siswa. in jurnal matematika dan pendidikan matematika. 1(2), 103-112.
Puccio, G. J., Burnett, C., Acar, S., Yudess, J. A., Holinger, M., \& Cabra, J. F. (2020). Creative Problem Solving in Small Groups: The Effects of Creativity Training on Idea Generation, Solution Creativity, and Leadership Effectiveness. Journal of Creative Behavior, 54(2), 453-471. https://doi.org/10.1002/jocb.381

Samara, D. (2016). Pengaruh Penerapan Model Pembelajaran Dan Motivasi Belajar Terhadap Hasil Belajar Siswa Pada Mata Pelajaran Ips Di Smp Negeri Model Terpadu Madani Palu. Katalogis, 4(7), 205214.

Semiz, G. K. (2020). Middle school preservice mathematics teachers' opinions related to mathematics education for sustainability. Eurasian Journal of Educational Research, 2020(89), 111-136. https://doi.org/10.14689/ejer.2020. 89.6

Sugiaryo \& Sutoyo. (2019). Penerapan Model Pembelajaran Cooperative Learning untuk Meningkatkan Motivasi Belajar pada Mata Kuliah Kapita Selekta Pendidikan Mahasiswa FKIP UNISRI. 13(2), 115-132.

https://doi.org/10.30957/cendekia. v13i2.600.Motivasi

Süße, T. (2020). Digital citizenship behavior in organization as indicator for actors' co-creative problem-solving in ecosystemoriented work environments. Advances in Intelligent Systems and Computing, Vol. 1018, pp. 675-681. https://doi.org/10.1007/978-3-03025629-6_105 
DOI: https://doi.org/10.24127/ajpm.v10i4.4143

Symonenko, S. V. (2020). Virtual reality in foreign language training at higher educational institutions. CEUR Workshop Proceedings, Vol. 2547, pp. 37-49. Retrieved from

https://api.elsevier.com/content/abs tract/scopus_id/85079570906

Tan, S. (2020). Assessing creative problem solving ability in mathematics: The DISCOVER Mathematics Assessment. Gifted and Talented International, 35(1), 58-71.

https://doi.org/10.1080/15332276.2 020.1793702

Uszyńska-Jarmoc, J. (2020). Students and Teachers Implicit and Explicit Theories of Creativity. Creativity, 6(2), 223-249. https://doi.org/10.1515/ctra-20190013
Wahyuningsih, S. (2020). An integration of "online interactive apps" for learning application of graph theory to enhance creative problem solving of mathematics students. International Journal of Interactive Mobile Technologies, 14(12), 97-109. https://doi.org/10.3991/IJIM.V14I1 2.15583

Zhang, D. (2020). The Effects of an Autonomy-Supportive Teaching Intervention on Chinese Physics Students and their Teacher. Research in Science Education, 50(2), 645-671. https://doi.org/10.1007/s11165018-9706-y 